\title{
Fertirrigation for Vegetables Grown in Greenhouses
}

\section{Fernando Ferrari Putti ${ }^{1}$, Camila Pires Cremasco ${ }^{2}$, Luís Roberto Almeida Gabriel Filho ${ }^{3}$, André Rodrigues do Reis ${ }^{3}$}

\author{
${ }^{1}$ Department of Agricultural Engineering, School of Agricultural Sciences, University of Estadual Paulista, \\ Botucatu-SP, Brazil \\ ${ }^{2}$ Department of Adminstration, College of Agricultural Sciences, University of Estadual Paulista, Tupã-SP, Brazil \\ ${ }^{3}$ Department of Biosystems Engineering, College of Agricultural Sciences, University of Estadual Paulista, \\ Tupã-SP, Brazil
}

Received: October $4^{\text {th }}, 2014$; Revised: November $19^{\text {th }}, 2014$; Accepted: November $21^{\text {st }}, 2014$

\section{Abstract}

Purpose: Concerns over the quantity of available freshwater for agriculture have triggered the development of technologies intended to increase efficiency of water use, especially with regard to irrigation. A new technique called fertirrigation has been developed to use the same irrigation equipment for fertilization. Methods: Since the above-mentioned technique requires care during installation and use on farms, current analysis focuses on some of its characteristics. Results: High uniformity irrigation systems provide the best distribution of fertilizers, especially when used in combination with drip irrigation or micro-aspersion. The factors purity, compatibility, acidification, salinity, and solubility should be taken into account. Conclusions: Fertirrigation provides a significant increase in productivity as it allows for highly controlled nutrient application during the entire growing season. However, it may cause serious problems if misused or overused.

Keywords: Economic, Fertirrigation, Irrigation, Production, Quality

\section{Introduction}

Recent concerns over the volume of freshwater used in agriculture have triggered the development of technologies intending to improve efficiency, especially in irrigation management, as a decrease in water use lowers production costs. Table 1 shows how the evolution of irrigation systems has led to greater efficiency.

A technique called fertirrigation has since been developed to allow for fertilizer application using existing irrigation equipment. The process has seen increasing use on farms due to its high degree flexibility. In fact, a unique feature of this method is its ability to allow precise tailoring of the quantity of fertilizer applied to a plant's phenological stage.

\footnotetext{
*Comesponding author: Fernando Ferrari Putti

E-mail: fernandoputti@fca.unesp.br

http://orcid.org/0000-0002-0555-9271
}

Several studies show that when administered correctly this technique produces higher yield and better product quality than traditional fertilizer application methods. Adverse effects that other fertilization methods of soil could cause to the environment, such as leaching and soil and water salinization, would be avoided. Several studies indicate that the proposed methods, can increase yield (Castellanos, et al., 2013b), as well as increase the quality of the product (Castellanos et al., 2013a). There is a great deal of promising

\begin{tabular}{cc} 
Table 1. Efficiency of the main types of irrigation systems \\
Irrigation methods & Efficiency of the irrigation system \\
Flooding & $40 \%-60 \%$ \\
Ridge & $50 \%-70 \%$ \\
Self-driven & $75 \%-80 \%$ \\
Aspersion & $70 \%-85 \%$ \\
Central pivot & $80 \%-90 \%$ \\
\hline
\end{tabular}

Source: Bernardo (2008). 
research into the reuse of wastewater in agriculture as a method of fertirrigation (Mohsin et al., 2014).

The purpose of this article is to provide a systemic review of existing fertirrigation research and present the characteristics of various fertilizers, as well as the agronomic benefit of the described methods.

\section{Practice}

Effective fertirrigation is primarily dependent on proper fertilizer selection and affected by the type of irrigation system used in application. Irrigation systems with a high degree of uniformity are those that provide the best fertilizer distribution. The system providing the greatest uniformity and efficiency is the drip or microaspersion system. Table 2 shows the main differences and similarities between irrigation systems used for fertirrigation.

\section{Main fertilizers and application types.}

According to Papadopoulos (1999) and Fonseca et al. (2009), the efficiency of fertirrigation is related to the irrigation system used. Systems with low water distribution uniformity and efficiency provide less benefit. Table 3 shows that the absorption of nutrients is higher in localized irrigation systems.

The fertilizers for fertirrigation must have the following characteristics: 1 ) They should be free from granulometry guarantee. 2) They should be indicated as "FERTILIZERS FOR FERTIRRIGATION". 3) Solubility (gL ${ }^{-1}$ at $20^{\circ} \mathrm{C}$ ), Salinity index $\left(\mathrm{dS} \mathrm{m}^{-1}\right)$ information must be given.

The main commercial manures used in fertirrigation are listed below (Fonseca et al., 2009), Nitrogen sources: urea, ammonium nitrate, ammonium sulfate, calcium nitrate, and potassium nitrate; Potassium sources: white potassium chlorate, potassium sulfate, and potassium nitrate; Phosphorus sources: phosphoric acid, MAP; Micronutrient sources: manganese sulfate, zinc sulfate, and boric acid.

In the interest of maximizing efficiency and minimizing potential damage to soils and irrigation systems, solubility, purity, compatibility, acidification, and salinity should all be considered as important factors in fertilizer selection.

\section{Solubility}

The solubility of a fertilizer is the maximum quantity that can be dissolved in $100 \mathrm{~mL}$ of water. Improper preparation of fertilizer solutions may ultimately damage irrigation equipment, as any remaining undissolved grains can clog its mechanisms. In addition, overapplication of fertilizer increases soil salinity and acidification.

According to Villas Bôas (1999), water temperature should also be monitored since smaller amounts of fertilizers dissolve in cold water. Table 4 shows the primary fertilizers and their respective solubility in water at $20^{\circ} \mathrm{C}$.

Table 2. Difference between irrigation systems and applications of fertilizers

\begin{tabular}{|cccc}
\hline Characteristics & Drip and microaspersion & Aspersion & Ridge \\
Use of water & High efficiency & low efficiency & Low efficiency \\
\hline Frequency of application & high & high & low \\
Distribution of water & homogeneous & homogeneous & not homogeneous \\
Distribution of manure & Close to the root system & Whole area & Varies along the ridge \\
Climate variations & Low limits & high limits & high limits \\
Water quality (salts) & high limits & low limits & low limits \\
Water impurity and fertilizers & High limits & low limits & low limits \\
Root system & restricted & without restrictions & without restrictions
\end{tabular}

Source: Fonseca (2009) apud Villas Bôas et al. (1999) (modified).

Table 3. Irrigation system and absorption of $\mathrm{N}, \mathrm{P}$, and $\mathrm{K}(\%)$

\begin{tabular}{cccc} 
System* & Nitrogen $(\mathrm{N})$ & Phosphorus (P) & Potassium (K) \\
Ridge & $40-60 \%$ & $10-20 \%$ & $60-70 \%$ \\
Aspersion & $60-70 \%$ & $20-25 \%$ & $70-80 \%$ \\
Localized irrigation & $75-85 \%$ & $25-35 \%$ & $80-90 \%$ \\
\hline
\end{tabular}

*system with a good size and functioning.

Source: Fonseca (2009) apud Papadopolus (1999). 
Table 4. Solubility at $20^{\circ} \mathrm{C}$ for commonly used fertilizers

\begin{tabular}{|c|c|}
\hline Fertilizers & Solubility $\left(\mathrm{g} \mathrm{L}^{-1}\right)$ \\
\hline \multicolumn{2}{|c|}{ Nitrogenated $(\mathrm{N})$} \\
\hline Ammonium nitrate & 1180 \\
\hline Calcium nitrate & 1020 \\
\hline Ammonium sulfate & 710 \\
\hline Urea & 780 \\
\hline Sodium nitrate & 730 \\
\hline \multicolumn{2}{|c|}{ Phosphates (P) } \\
\hline Super triple phosphate & 40 \\
\hline Phosphoric acid & 457 \\
\hline \multicolumn{2}{|c|}{ Potassium (K) } \\
\hline Potassium chlorate & 340 \\
\hline Potassium sulfate & 110 \\
\hline \multicolumn{2}{|c|}{$\mathrm{N}$ and $\mathrm{P}$} \\
\hline MAP & 230 \\
\hline Purified MAP & 370 \\
\hline Dap & 400 \\
\hline \multicolumn{2}{|c|}{$\mathrm{N}$ and $\mathrm{K}$} \\
\hline Potassium nitrate & 320 \\
\hline \multicolumn{2}{|c|}{ with $\mathrm{Ca}$ and $\mathrm{Mg}$} \\
\hline Pentahydrated calcium chlorate & 670 \\
\hline Magnesium sulfate & 710 \\
\hline Chalk & 2.41 \\
\hline \multicolumn{2}{|c|}{ Containing } \\
\hline Borax & 50 \\
\hline Copper sulfate & 220 \\
\hline Pentahydrated copper sulfate & 240 \\
\hline Iron sulfate & 240 \\
\hline Ferrous sulfate & 330 \\
\hline Manganese sulfate & 1050 \\
\hline Zinc sulfate & 750 \\
\hline Quelates ( $\mathrm{Fe}, \mathrm{Cu}, \mathrm{Mn}$, and $\mathrm{Zn}$ ) & High \\
\hline
\end{tabular}

Source: Fonseca (2009) apud Villas Bôas et al.(1999) (modified).

\section{Purity}

The fertilizer's impurity rates in fertirrigation are highly relevant to the proper preparation of the solution. In fact, some fertilizers contain oil, paraffin, clay, and stony elements that may cause clogging to irrigation systems (Fonseca et al., 2009). Table 5 displays the most common commercial products used for fertirrigation and their purity percentage.

\section{Compatibility}

The characteristics of the water employed are highly
Table 5. Purity percentage of some fertilizers

\begin{tabular}{|cc|}
\hline Nutrient source & Purity (\%) \\
\hline Potassium nitrate & 95 \\
\hline Calcium nitrate & 95 \\
\hline Ammonium sulfate & 94 \\
\hline Ammonium nitrate & 98 \\
\hline Potassium chlorate & 95 \\
\hline Potassium sulfate & 90 \\
\hline Calcium chlorate & 75 \\
\hline Ammonium sulfate & 94 \\
\hline
\end{tabular}

Source: Medeiros et al. (2011) and Resh (2001).

relevant when dealing with the compatibility of different fertilizers for joint use in fertirrigation, since they may jeopardize the system. We will thus investigate the relevant water characteristics and compatibility between the fertilizers.

\section{Water for fertirrigation}

According to Medeiros (2011), water for fertirrigation should have certain characteristics that provide specific physical, chemical, and biological traits of the following types: 1) Electrical conductivity (amount of salts), 2) Sodium concentration (relevant to sodium absorption), 3) Clogging risk - Physical (pebbles, sand grains), Chemical (salts, iron), Biological (algae, fish), 4) Acidity and buffer conditions, 5) Sulfated ion concentration.

\section{Fertilizers}

When different types are used in combination, fertilizers for fertirrigation should not be mixed prior to verification of whether they are compatible. The precipitation of new compounds would result from improper combinations and may damage the irrigation system.

Tests of fertilizer compatibility should be assayed in small proportions when preparing the solution. Table 6 presents the compatibility of the main fertilizers for fertirrigation.

\section{Acidification}

According to Coelho et al. (2000), the solution's pH should vary between 5.5 and 6.0, to avoid soil acidification; the best nutrition absorption rate of plants should occur between 6.0 and 6.5 (Malavolta, 2006). To avoid the negative effects caused by acidification or basification of the solution, nitric, phosphoric and sulfuric acids are used to reduce the effect. It should be emphasized that different concentrations 
Table 6. Compatibility between fertilizer mixtures

\begin{tabular}{|c|c|c|c|c|c|c|c|c|c|c|c|c|c|c|}
\hline & Urea & $\begin{array}{c}\text { Ammo- } \\
\text { nium } \\
\text { nitrate }\end{array}$ & $\begin{array}{l}\text { Ammo- } \\
\text { nium } \\
\text { sulfate }\end{array}$ & $\begin{array}{l}\text { Calcium } \\
\text { nitrate }\end{array}$ & $\begin{array}{l}\text { Potas- } \\
\text { sium } \\
\text { nitrate }\end{array}$ & $\begin{array}{l}\text { Potas- } \\
\text { sium } \\
\text { chlorate }\end{array}$ & $\begin{array}{l}\text { Potas- } \\
\text { sium } \\
\text { sulfate }\end{array}$ & $\begin{array}{c}\text { Ammo- } \\
\text { nium } \\
\text { phosp- } \\
\text { hate }\end{array}$ & $\begin{array}{c}\mathrm{Fe}, \mathrm{Zn}, \\
\mathrm{Cu}, \\
\text { and } \\
\mathrm{Mn}\end{array}$ & $\begin{array}{c}\mathrm{Fe}, \mathrm{Zn}, \\
\mathrm{Cu}, \\
\text { and } \\
\mathrm{Mn}\end{array}$ & $\begin{array}{l}\text { Magn- } \\
\text { esium } \\
\text { sulfate }\end{array}$ & $\begin{array}{l}\text { Phos- } \\
\text { phoric } \\
\text { acid }\end{array}$ & $\begin{array}{l}\text { Sulfuric } \\
\text { acid }\end{array}$ & $\begin{array}{l}\text { Nitric } \\
\text { acid }\end{array}$ \\
\hline Urea & - & - & - & - & - & - & - & - & - & - & - & - & - & - \\
\hline Ammonium nitrate & - & - & - & - & - & - & - & - & - & - & - & - & - & - \\
\hline Ammonium sulfate & - & - & - & - & - & - & - & - & - & - & - & - & - & - \\
\hline Calcium nitrate & - & - & a & - & - & - & - & - & - & - & - & - & - & - \\
\hline Potassium nitrate & - & - & - & - & - & - & - & - & - & - & - & - & - & - \\
\hline Potassium chlorate & - & - & - & - & - & - & - & - & - & - & - & - & - & - \\
\hline Potassium sulfate & - & - & $b$ & a & - & $b$ & - & - & - & - & - & - & - & - \\
\hline Ammonium phosphate & - & - & - & a & - & - & - & - & - & - & - & - & - & - \\
\hline $\mathrm{Fe}, \mathrm{Zn}, \mathrm{Cu}$, and $\mathrm{Mn}$ & - & - & - & a & - & - & $b$ & a & - & - & - & - & - & - \\
\hline $\mathrm{Fe}, \mathrm{Zn}, \mathrm{Cu}$, and $\mathrm{Mn}$ & - & - & - & $b$ & - & - & - & $b$ & - & - & - & - & - & - \\
\hline Magnesium sulfate & - & - & - & a & - & - & $b$ & a & - & - & - & - & - & - \\
\hline Phosphoric acid & - & - & - & - & - & - & - & - & a & $b$ & - & - & - & - \\
\hline Sulfuric acid & - & - & - & a & - & - & $b$ & - & - & - & - & - & - & - \\
\hline Nitric acid & - & - & - & - & - & - & - & - & - & a & - & - & - & - \\
\hline
\end{tabular}

a: Incompatible, b: Reduced solubility, -: Compatible

Source: Medeiros et al. (2011); Fonseca et al. (2009).

\section{Table 7. Tolerance to salinity}

\begin{tabular}{ccccc} 
& \multicolumn{4}{c}{ Probable decrease in productivity } \\
\cline { 2 - 5 } Culture & $0 \%$ & $10 \%$ & $25 \%$ & $50 \%$ \\
Cotton & 7.7 & 9.6 & 13 & 17 \\
Turnip & 1.0 & 1.7 & 2.8 & 4.6 \\
Maize & 1.7 & 2.5 & 3.8 & 5.9 \\
\hline Soybean & 5 & 5.5 & 6.2 & 7.5 \\
Orange & 1.7 & 2.3 & 3.3 & 4.8 \\
Lettuce & 1.3 & 2.1 & 3.2 & 5.2 \\
\hline
\end{tabular}

${ }^{*}$ Rates in mmhos $\mathrm{cm}^{-1}$, Source: Klar (1984) modified.

of fertilizers change the solution's $\mathrm{pH}$.

\section{Electric Conductivity}

Electric conductivity (EC) of the solution is a measure of salinity, and it should not be allowed to exceed $2.0 \mathrm{dS}$ $\mathrm{m}^{-1}$. Many plants have a low tolerance to salinity, with salt stress leading to a decrease in yield. Some plant species are highly sensitive to salinity. Table 7 lists some saltsensitive plants and productivity decreased caused by increasing salinity.

\section{Advantages and disadvantages}

The fertirrigation technique has several advantages when correctly used. The main advantages and disadvantages are listed below, following Fonseca et al. (2009), Soares (2001), Oliveira et al. (2005), Esteves et al. (2012):

The main advantages are controlled doses of fertilizer, increase in fruit production and quality, low labor costs, increase in nutrient availability to plants, increase in absorption efficiency, decrease of losses by leaching, decrease of pathogen and burnt leaves, decrease in personnel and machine movement, better benefits from irrigation equipment, less impacting of soil, and decreased physical damage to the culture.

The main disadvantages are the possibility of fertilizer runoff into local water sources, the possibility of clogging and tube corrosion, increased soil salinity or acidification, high implementation costs, and the cost of expert labor. It must be highlighted that the irrigation system may be used not only for fertirrigation but also for the application of pesticides. Although there are risks associated with such a technique, it should be emphasized that it is a viable way to increase productivity and product quality and decrease operating costs, which will eventually increase the farm's profit.

\section{Conclusions}

Fertirrigation is a technique effectively used to increase production as it allows for controlled nutrient application 
during the entire growing season. However, misapplication of the technique will lead to crop and equipment damage.

Within the context presented, it can be inferred that the correct handling of fertirrigation can assist the producer in many senses. In reducing their time spent applying fertilizer also should emphasize waste reduction, the technique is much more efficient.

Fertilizers used should be of high purity, as high levels of impurities can damage irrigation systems and combinations of fertilizers can generate a precipitate when mixed because both lead to clogging of the system and loss of the fertilizer.

\section{Conflict of Interest}

The authors have no conflicting financial or other interests.

\section{Acknowledgments}

The authors would like to thank the Postgraduate Program in Agronomy - Irrigation and Drainage, CNPQ and CAPES for funding the scholarship for Master's and Doctoral Degrees. Thanks are also due to the personnel of the Department of Rural Engineering.

\section{References}

Bernardo, S. and M. de Irrigação. 2008. Viçosa: Editora UFV, 625p.

Castellanos, M. T., A. M. Tarquis, F. Ribas, M. J. Cabello, A. Arce and M. C. Cartagena. 2013a. Nitrogen fertigation: An integrated agronomic and environmental study. Agricultural Water Management 120(31):46-55.

Castellanos, M. T., M. C. Cartagena, F. Ribas, M. J. Cabello, A. Arce and A. M. Tarquis. 2013b. Impact of nitrogen uptake on field water balance in fertirrigated melon. Agricultural Water Management 120(31):56-63.

Coelho, E. F. Cálculo e preparo da solução de fertilizantes.
In: Borges, A. L., Coelho, E. F., Trindade, A. V. (Org.). Fertirrigação em fruteiras tropicais. Cruz das Almas: Embrapa Mandioca e Fruticultura, 2002. p. 54-67.

Coelho, E. F., Oliveira, A. M. G., Silva, T. S. M., Santos, D. B. dos. Produtividade do mamoeiro sob diferentes doses de nitrogênio e de potássio aplicados via água de irrigação. In: Folegatti, M. V., Casarini, E., Blanco, F. F., Brasil, R. P. C. do, Rezende, R. S. (Org.). Fertirrigação: flores, frutas e hortaliças. Guaíba: Agropecuária, 1, 78-87.

Esteves, B. DOS S., DA silva, D.G., Paes, H.M.F., DE Sousa, E.F. 2012. Manual técnico: Irrigação por gotejamento. 32.ed. Rio de Janeiro, 18p.

Fonseca, A.S., Carribeiro, L.S., Souza, T.R., Foratto, L.C., Villas Bôas, R.L. A técnica da fertirrigação. 2009. In: Salomão, L. C.; Sanches, L.V.C.; Saad, J. C. C.;Villas Bôas, R. L. Manejo de irrigação. Um guia prático para o uso racional da água. 1.ed. Botucatu: FEPAF, 87-114.

Papadoupolos, I. 1999. Fertirrigação: situação atual e perspectivas para o futuro. In: FOLLEGATTI, M. V. (ed.). Fertirrigação: citros, flores, hortaliças. Guaíba: Agropecuária, p.111-169.

Medeiros, J. F. De, Sousa, V. F De, Maia, C. E., Coelho, E. F., Marouelli, W. A. 2011. Determinação e preparo da solução de fertilizantes para fertirrigação. In: Sousa, V. F DE, Marouelli, W. A., Coelho, E. F., Pinto, J. M., Coelho Filho, M. A. Irrigação e Fertirrigação e fruteiras e hortaliças. 1.ed. Brasília: Embrapa Informação Tecnológica, 265-288.

Klar, A. E. 1984. A Água no Sistema Solo Planta Atmosfera, 1 Ed. São Paulo, 408.

Soares, A. R. Irrigação, fertirrigação, fisiologia e produção em cafeeiros adultos na região da zona da mata de minas gerais. 2001. 99F. Master's dissertation in Agricultural Engineering, Universidade Federal de Viçosa, Viçosa, Brazil.

Villas Bôas, R. L., Büll, L.T., Fernandes, D. M. 1999. Fertilizantes em fertirrigação. In: FOLLEGATTI, M. V. (ed.). Fertirrigação: citros, flores, hortaliças. Guaíba: Agropecuária, 293-319. 